\title{
Meningkatnya Kemampuan Guru Melaksanakan Proses Pembelajaran dengan Adanya Supervisi Klinis
}

\section{${ }^{*}$ Imelda $^{1}$}

${ }^{1}$ SD 2 Petandakan, Buleleng, Indonesia

\section{A R T I C L E I N F O}

Article history:

1 Maret 2020 Received in revised form

30 Maret 2020

Accepted 11 April 2020

Available online 15

Mei 2020

\section{Kata Kunci:}

Supervisi klinis,

melaksanakan proses

pembelajaran

Keywords:

clinical supervision, ability

to carry out the learning

proces

yaitu pada prasiklus sebesar $65,42 \%$ mang kemampuan guru melaksanakan proses pembelajaran tergolong cukup, dan pada siklus II menjadi $82,60 \%$ yang tergolong baik. Dengan adanya supervisi klinis dapat membatu guru-guru yang mengalami kesaulitan dalam proses proses pembelajaran.

\section{A B S T R A C T}

The teachers' skills in teaching are still far from what is expected. Sometimes the teachers teaching improperly do not prepare the subject matter properly. This problem affects the learning process. The aim of this action research was to improve the teachers' ability to carry out the learning process in elementary school teachers through the implementation of clinical supervision. This research was conducted in two cycles. The design of each cycle consisted of four stages. Based on the data obtained it could be concluded that the implementation of clinical supervision could be improved the teachers'ability to carry out the learning process at the SD Negeri 2 Petangkap on the second semester in the academic year 2019/2020. This could be seen from the improvement of the teachers'ability to carry out the learning process. On the pre-cycle, the level of percentage $65.42 \%$ which was classified as sufficient, on the second cycle it improved to $73.96 \%$ which was classified as sufficient, and on cycle two, it improved to $82.60 \%$ which was classified as good.

\section{Pendahuluan}

Guru yang profesional adalah guru yang memiliki kompetensi yang diperlukan sesuai bidang keguruan. Kompetensi yang harus dimiliki oleh guru lebih lanjut tertera dalam Undang-Undang RI Nomor 14 Tahun 2005 Tentang Guru dan Dosen yang termuat dalam Bab IV Pasal 10 ayat (1), yang menyatakan bahwa "Kompetensi guru meliputi kompetensi pedagogik, kompetensi kepribadian, kompetensi sosial, dan kompetensi profesional yang diperoleh melalui pendidikan profesi". Undang-Undang di atas menjelaskan bahwa salah satu kompetensi yang harus dimiliki oleh guru yaitu kompetensi pedagogik. Kompetensi ini merupakan kompetensi yang mencerminkan kemampuan mengajar seorang guru . Menurut Anwar (2018) kompetensi guru dapat dimaknai sebagai gambaran tentang apa yang harus dilakukan seorang guru dalam melaksanakan pekerjaannya, baik berupa kegiatan, perilaku, maupun hasil 
yang dapat ditunjukkan dalam proses belajar mengajar. Kompetensi guru menjadi salah satu penentu keberhasilan dalam proses belajar (Yurizki, 2018)

Peraturan menteri Pendidikan dan Kebudayaan No. 16 Tahun 2007 tentang Standar Kompetensi Akademik dan Kompetensi Guru juga mengatur tentang 4 kompetensi yang harus dikuasai. Kompetensi pedagogik sebagaimana dimaksud pada ayat (2) Undang-Undang RI Nomor 14 Tahun 2005 Tentang Guru dan Dosen, merupakan kemampuan guru dalam pengelolaan pembelajaran peserta didik yang sekurangkurangnya meliputi pemahaman wawasan atau landasan kependidikan, pemahaman terhadap peserta didik, pengembangan kurikulum/silabus, perancangan pembelajaran, pelaksanaan pembelajaran yang mendidik dan dialogis, pemanfaatan teknologi pembelajaran, evaluasi hasil belajar, dan pengembangan peserta didik untuk mengaktualisasikan berbagai potensi yang dimilikinya (Sulfemi, 2015)Seorang guru disebut sebagai guru profesional apabila memiliki kemampuan dalam mewujudkan kinerja profesi guru dengan sebaik-baiknya dalam mencapai tugas keprofesionalannya (Syaidah, 2018). Menurut Supriyono, (2017) Guru profesional menjadi faktor penentu proses pendidikan yang berkualitas. Guru harus mampu menemukan jati diri dan mengaktualisasikannya sesuai dengan kemampuan dan kaidah guru profesional.

Berdasarkan pernyataan di atas, dapat disimpulkan bahwa untuk dapat mengajar dengan baik maka guru harus menguasai teori dan praktek pedagogik dengan baik, seperti memahami karakter peserta didik, dapat menjelaskan materi pelajaran dengan baik, mampu memberikan evaluasi terhadap apa yang sudah diajarkan, dan mampu mengembangkan potensi yang dimiliki oleh peserta didik, karena hal inilah yang dapat membuat guru menjadi terampil didalam melaksanakan tugas dalam mengajar sehari-hari. Dalam proses pembelajaran, seorang guru perlu merancang terlebih dahulu program pembelajarannya, artinya seorang guru sebelum mengajar perlu merancang pengorganisasian bahan pelajaran yang jelas, merancang pengelolaan kelas, merancang strategi pembelajaran, merancang media pembelajaran serta merancang evaluasi pembelajaran siswa (Fitriani, 2017).

Kenyataan yang terjadi di lapangan berdasarkan hasil observasi, keterampilan guru masih jauh dari apa yang diharapkan, terkadang guru mengajar seadanya, tidak menyiapkan materi pelajaran dengan baik. Hal ini seperti yang di ungkap oleh Mulyasa, (2005) yang menyatakan ada tujuh kesalahan yang sering dilakukan oleh guru khususnya dalam proses pembelajaran yaitu antara lain mengambil jalan pintas dalam pembelajaran (tidak membuat persiapan tertulis dalam mengajar), menunggu siswa berperilaku negatif (guru tidak memberikan perhatian dan penghargaan yang pantas kepada siswa yang berperilaku baik, sehingga siswa memiliki kesimpulan kalau ingin mendapat perhatian dari guru harus berperilaku yang negatif), menggunakan destructif disiplin (guru menggunakan disiplin yang dapat merusak perkembangan siswa), mengabaikan perbedaan siswa, merasa paling pandai, tidak adil (diskriminatif), memaksa hak peserta didik.

Banyak sekali keterampilan yang harus dimiliki oleh guru, dan untuk menguasai keterampilanketerampilan tersebut guru membutuhkan bimbingan dan pembinaan intensif yang dapat meningkatkan keterampilannya didalam mengajar. Kurangnya bimbingan dan pembinaan terhadap guru dapat menyebabkan guru melakukan kesalahan-kesalahan di dalam mengajar. Hal ini juga dapat diartikan bahwa kesalahan-kesalahan yang dilakukan oleh guru pada saat mengajar disebabkan oleh kurang adanya pembinaan dari kepala sekolah selaku pemegang kekuasaan tertinggi di sekolah.

Kepala sekolah merupakan salah satu komponen yang paling berperan dalam meningkatkan mutu pendidikan di sekolah (Banun, 2016). Untuk mengatasi masalah kurangnya keterampilan guru dalam melaksanakan proses pembeljaran kepala sekolah dapat menerapkan supervisi pendidikan yang sekarang tengah berkembang, yaitu supervisi klinis, dimana supervisi ini difokuskan untuk meningkatan kualitas mengajar melalui siklus yang sistematis. Menurut Agustini, (2019) Supervisi klinis adalah supervisi yang dilakukan oleh kepala sekolah untuk menunjang kompetensi guru dan TU sekolah. Supervisi sangat diperlukan oleh guru dalam meningkatkan profesionalisme-nya, sebagai upaya memperbaiki dan mengontrol segala aktivitas agar terlaksana secara optimal (Ranjawali, 2019). Hal ini diperkuat oleh Richard Waller (Purwanto, 2006) yang menjelaskan bahwa:

"Clinical Supervision may be defined as supervision focused upon the improvement of instruction by means of systematic cycles of planning, observation and intensive intellectual analysis of actual teacing performances in the interest of rasional modification."

Dari pemaparan di atas, maka dapat diartikan bahwa Supervisi Klinis adalah supervisi yang difokuskan pada perbaikan pengajaran dengan melalui siklus yang sistematis, dari tahap perencanaan, pengamatan, dan analisis intelektual yang intensif terhadap penampilan mengajar sebenarnya dengan tujuan untuk mengadakan modifikasi yang rasional. Dengan implementasi supervisi klinis, kepala sekolah dapat membantu guru dalam memperbaiki dan meningkatkan keterampilannya pada saat mengajar di dalam kelas. Hal ini seperti yang dikemukakan oleh (Sagala, 2020) bahwa supervisi klinis dalam proses pembelajaran di kelas dapat memperbaiki dan meningkatkan keterampilan guru. (Salma, 2018) juga mengungkapkan supervisi klinis merupakan usaha melihat dan menemukan titik kelemahan serta 
hambatan dalam pembelajaran, kemudian diusahakan untuk dapat memperbaiki kelemahan tersebut, dengan menggunakan siklus yang sistematis, yang dimulai dari perencanaan, pengamatan,dan tahapan umpan balik. Pada akhirnya akan mempermudah guru dalam meningkatkan profesionalisme.

Supervisi klinis yang juga disebut supervisi kelas adalah suatu bentuk bimbingan atau bantuan profesional yang diberikan kepada guru berdasarkan kebutuhan guru melalui siklus yang sistematis untuk meningkatkan proses belajar mengajar. Etos kerja pada diri seseorang guru akan lahir semangat untuk menjalankan tugas dengan sungguh-sungguh, adanya keyakinan bahwa dengan berusaha secara maksimal hasil yang akan didapat tentunya maksimal pula.

Dalam hubungannya dengan kemampuan guru dalam mengajar atau mengelola proses pembelajaran, para guru memerlukan bimbingan yang sifatnya kolegalitas dan motivasi kerja yang tinggi, agar mampu melaksanakan proses pembelajaran sesuai dengan stándar proses. Melalui supervisi klinis, tercipta hubungan manusiawi sehingga guru-guru memiliki rasa aman.Dalam hubungan ini bantuan yang diberikan tidak bersifat instruksi atau memerintah, sehingga diharapkan adanya kesediaan untuk menerima perbaikan. Suasana dalam pemberian supervisi adalah suasana yang penuh kehangatan, kedekatan, dan keterbukaan, dan tidak saja pada keterampilan mengajar tapi juga mengenai aspek-aspek kepribadian guru, misalnya motivasi terhadap gairah mengajar.

Melalui supervisi klinis yang yang berbentuk siklus dan bersifat kelegalitas, diharapkan kemampuan guru-guru dalam melaksanakan pembelajaran dapat meningkat. Berdasarkan latar belakang tersebut, maka rumusan masalah dalam penelitian ini adalah apakah implementasi supervisi klinis dapat meningkatkan kemampuan melaksanakan proses pembelajaran pada guru SD Negeri 2 Petandakan semester II tahun pelajaran 2019/2020?

Tujuan penelitian ini ini adalah untuk meningkatkan kemampuan melaksanakan proses pembelajaran pada guru SD Negeri 2 Petandakan semester II tahun pelajaran 2019/2020 melalui implementasi supervisi klinis.

\section{Metode}

Penelitian tindakan sekolah ini dilaksanakan di SD Negeri 2 Petandakan tempat penulis bertugas sebagai kepala sekolah. Pelaksanan penelitian tindakan sekolah ini dilaksanakan pada semester II tahun pelajaran 2019/2020. Subjek dari penelitian ini adalah guru-guru SD Negeri 2 Petandakan yang berjumlah 8 orang. Sedangkan objek penelitiannya adalah tentang kemampuan guru dalam melaksanakan proses pembelajaran. Penelitian ini termasuk penelitian tindakan sekolah. Elliot memaparkan action research pertama kalinya diperkenalkan oleh Kurt Lewin dengan menggunakan siklus spiral. Adapun langkah-langkahnya terdiri dari perencanaan (planning), pelaksanaan (acting), pengamatan (observing), dan refleksi (reflecting). Pertama, Pada tahap perancanaan dilaksanakan perencanaan tahapan pelaksanaan supervisi klinis dan menyiapkan lembar observasi. Kedau, Pada tahap pelaksanaan, diawali dengan dialog dengan guru untuk mengetahui kendala atau hambatan dalam pelaksanaan proses pembelajaran. Dilanjutkan dengan berdiskusi untuk mencari solusinya. Kemudian guru menyusun RPP untuk dilaksanakan pada proses pembelajaran pada saat diobservasi. Ketiga, Kegiatan observasi terhadap kemampuan guru dalam melaksanakan proses pembelajaran yang dilaksanakan ketika proses pembelajaran berlangsung. Data kemempuna guru tersebut dituankan dalam lembar observasi. Keempat, Pada tahap refleksi dilakukan analisis data hasil observasi untuk menentukan langkah selanjutnya. Adapun pada tabel 1 adalah instrumen yang digunakan untuk memperoleh data tentang kemampuan guru dalam melaksanakan proses pembelajaran adalah berupa lembar observasi yang dikembangkan sendiri oleh peneliti mengacu pada pelaksanaan proses pembelajaran seperti yang tertuang dalam standar proses.

Tabel 1. Instrumen Penilaian Proses Pembelajaran

\begin{tabular}{lll}
\hline No & Aspek yang Dinilai & Skor \\
\hline I & PRA PEMBELAJARAN & \\
1 & Memeriksa kesiapan siswa & \\
2 & Melakukan kegiatan apersepsi & \\
& & \\
II & KEGIATAN INTI PEMBELAJARAN & \\
A & Penguasaan Materi Pembelajaran & \\
3 & Menunjukkkan penguasaan materi pembelajaran & \\
4 & Mengaitkan materi dengan penguasaan lain yang relevan & \\
5 & Menyampaikan materi dengan jelas dan sesuai dengan hirarkhi belajar &
\end{tabular}




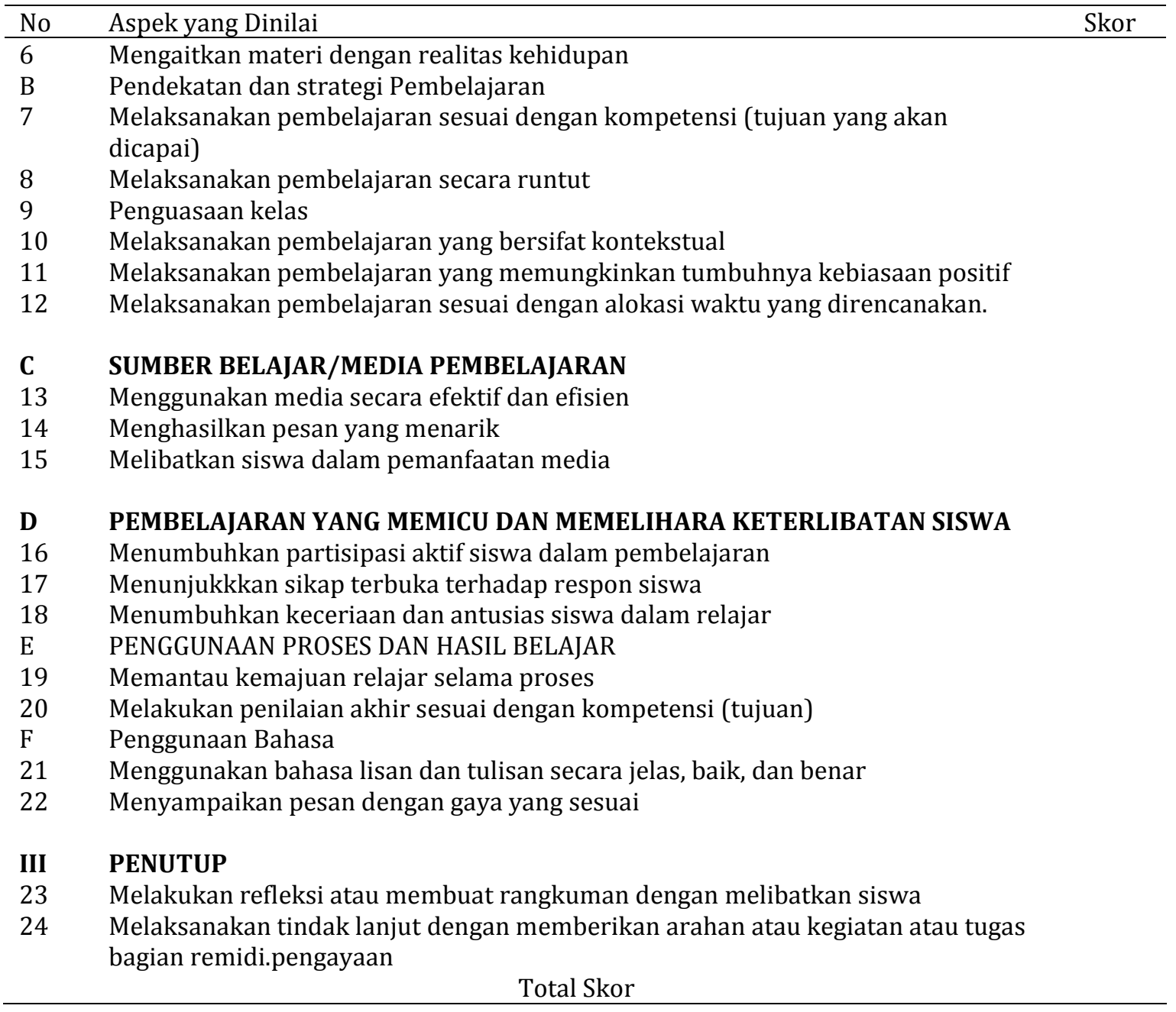

Tabel 2. Rubrik Penilaian Pelaksanaan Pembelajaran

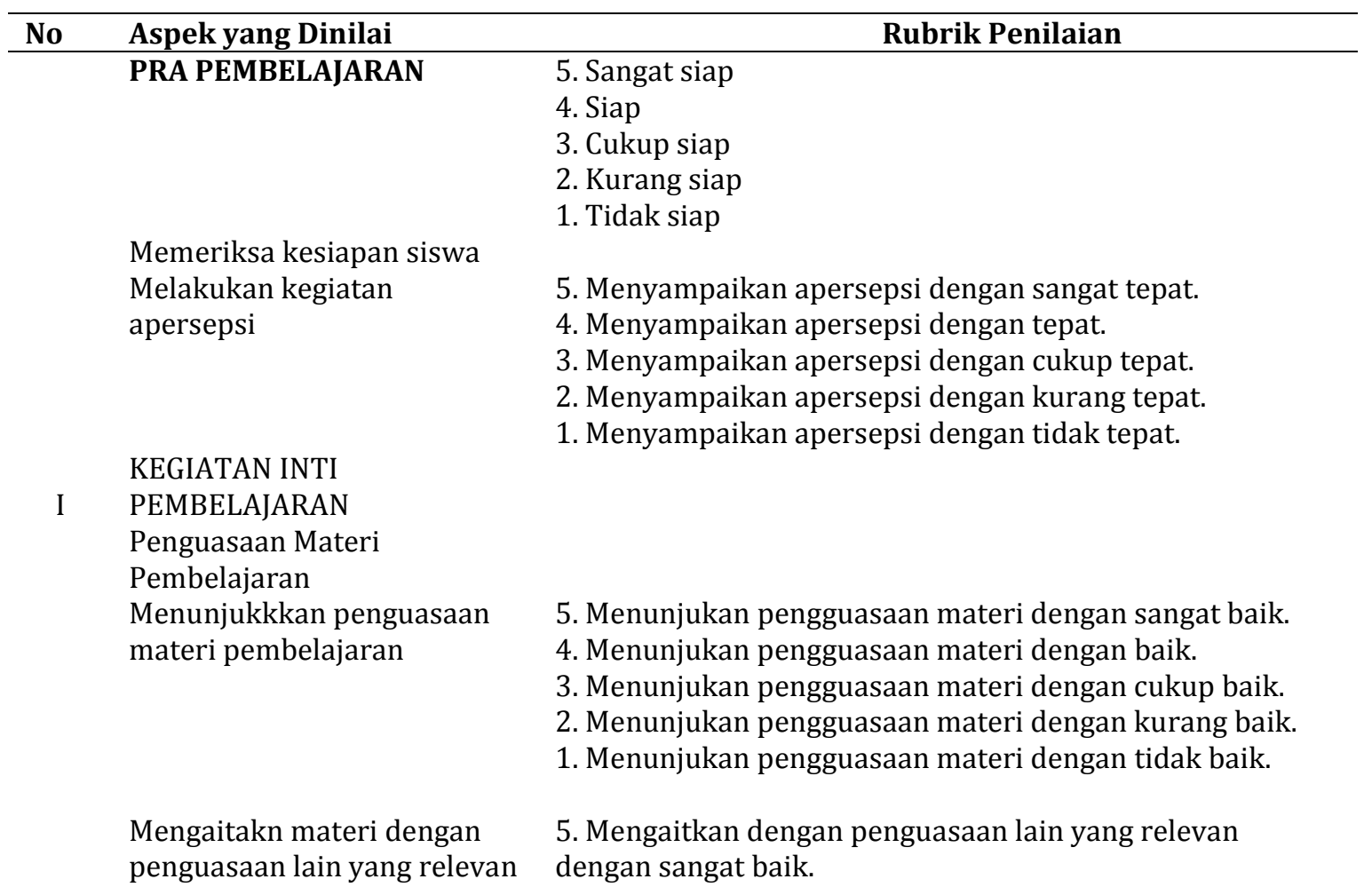




\begin{tabular}{ll}
\hline No $\quad$ Aspek yang Dinilai & \multicolumn{1}{c}{ Rubrik Penilaian } \\
\hline & 4. Mengaitkan dengan penguasaan lain yang relevan \\
dengan baik. & 3. Mengaitkan dengan penguasaan lain yang relevan \\
& dengan cukup baik. \\
& 2. Mengaitkan dengan penguasaan lain yang relevan \\
& dengan kurang baik. \\
& 1. Mengaitkan dengan penguasaan lain yang relevan \\
& dengan tidak baik. \\
& 5. Menyampaikan materi dengan sangat jelas. \\
Menyampaikan materi & 4. Menyampaikan materi dengan jelas. \\
dengan jelas dan sesuai & 3. Menyampaikan materi dengan cukup jelas. \\
dengan hirarkhi belajar & 2. Menyampaikan materi dengan kurang jelas. \\
& 1. Menyampaikan materi dengan tidak jelas. \\
& 5. Mengaitkan materi dengan realitas kehidupan dengan \\
Mengaitkan materi dengan & sangat baik. \\
realitas kehidupan & 4. Mengaitkan materi dengan realitas kehidupan dengan \\
& baik. \\
& 3. Mengaitkan materi dengan realitas kehidupan dengan \\
& cukup baik. \\
& 2. Mengaitkan materi dengan realitas kehidupan dengan \\
& kurang baik. \\
& 1. Mengaitkan materi dengan realitas kehidupan dengan \\
& tidak baik.
\end{tabular}

Pendekatan dan strategi

Pembelajaran

Melaksanakan pembelajaran sesuai dengan kompetensi (tujuan yang akan dicapai)

5. Melaksanakan pembelajaran sesuai dengan kompetensi dengan sangat baik.

4. Melaksanakan pembelajaran sesuai dengan kompetensi dengan baik.

3. Melaksanakan pembelajaran sesuai dengan kompetensi dengan cukup baik.

2. Melaksanakan pembelajaran sesuai dengan kompetensi dengan kurang baik.

1. Melaksanakan pembelajaran sesuai dengan kompetensi dengan tidak baik

Melaksanakan pembelajaran secara runtut

Penguasaan kelas

Melaksanakan pembelajaran yang bersifat kontekstual
5. Melaksanakan pembelajaran secara runtut dengan sangat baik.

4. Melaksanakan pembelajaran secara runtut dengan baik.

3. Melaksanakan pembelajaran secara runtut dengan cukup baik.

2. Melaksanakan pembelajaran secara runtut dengan kurang baik.

1. Melaksanakan pembelajaran secara runtut dengan tidak baik.

5. Penguasaan kelas sangat baik.

4. Penguasaan kelas baik.

3. Penguasaan kelas cukup baik.

2. Penguasaan kelas kurang baik.

1. Penguasaan kelas tidak baik.

5. Melaksanakan pembelajaran yang bersifat kontekstual dengan sangat baik.

4. Melaksanakan pembelajaran yang bersifat kontekstual 


\begin{tabular}{|c|c|c|}
\hline No & Aspek yang Dinilai & Rubrik Penilaian \\
\hline & & $\begin{array}{l}\text { dengan baik } \\
\text { 3. Melaksanakan pembelajaran yang bersifat kontekstı } \\
\text { dengan cukup baik } \\
\text { 2. Melaksanakan pembelajaran yang bersifat kontekstı } \\
\text { dengan kurang baik } \\
\text { 1. Melaksanakan pembelajaran yang bersifat kontekstı } \\
\text { dengan tidak baik }\end{array}$ \\
\hline 1 & $\begin{array}{l}\text { Melaksanakan pembelajaran } \\
\text { yang memungkinkan } \\
\text { tumbuhnya kebiasaan positif }\end{array}$ & $\begin{array}{l}\text { 5. Melaksanakan pembelajaran yang memungkinkan } \\
\text { tumbuhnya kebiasaan positif dengan sangat baik. } \\
\text { 4. Melaksanakan pembelajaran yang memungkinkan } \\
\text { tumbuhnya kebiasaan positif dengan baik. } \\
\text { 3. Melaksanakan pembelajaran yang memungkinkan } \\
\text { tumbuhnya kebiasaan positif dengan cukup baik. } \\
\text { 2. Melaksanakan pembelajaran yang memungkinkan } \\
\text { tumbuhnya kebiasaan positif dengan kurang baik. } \\
\text { 1. Melaksanakan pembelajaran yang memungkinkan } \\
\text { tumbuhnya kebiasaan positif dengan tidak baik. }\end{array}$ \\
\hline
\end{tabular}

Melaksanakan pembelajaran sesuai dengan alokasi waktu yang direncanakan.

SUMBER BELAJAR/MEDIA PEMBELAJARAN

Menggunakan media secara

3 efektif dan efisien

Menghasilkan pesan yang menarik

Melibatkan siswa dalam

5 pemanfaatan media pembelajaran yang memicu dan memelihara keterlibatan siswa
5. Melaksanakan pembelajaran sesuai dengan alokasi waktu yang direncanakan dengan sangat baik.

4. Melaksanakan pembelajaran sesuai dengan alokasi waktu yang direncanakan dengan baik.

3. Melaksanakan pembelajaran sesuai dengan alokasi waktu yang direncanakan dengan cukup baik.

2. Melaksanakan pembelajaran sesuai dengan alokasi waktu yang direncanakan dengan kurang baik.

1. Melaksanakan pembelajaran sesuai dengan alokasi waktu yang direncanakan dengan tidak baik.

5. Menggunakan media secara efektif dan efisien dengan sangat baik.

4. Menggunakan media secara efektif dan efisien dengan baik.

3. Menggunakan media secara efektif dan efisien dengan cukup baik.

2. Menggunakan media secara efektif dan efisien dengan kurang baik.

1. Menggunakan media secara efektif dan efisien dengan tidak baik.

5. Menghasilkan pesan yang menarik dengan sangat baik.

4. Menghasilkan pesan yang menarik dengan baik.

3. Menghasilkan pesan yang menarik dengan cukup baik.

2. Menghasilkan pesan yang menarik dengan kurang baik.

1. Menghasilkan pesan yang menarik dengan tidak baik.

5. Melibatkan siswa dalam pemanfaatan media dengan sangat baik.

4. Melibatkan siswa dalam pemanfaatan media dengan baik.

3. Melibatkan siswa dalam pemanfaatan media dengan cukup baik.

2. Melibatkan siswa dalam pemanfaatan media dengan kurang baik.

1. Melibatkan siswa dalam pemanfaatan media dengan tidak baik. 


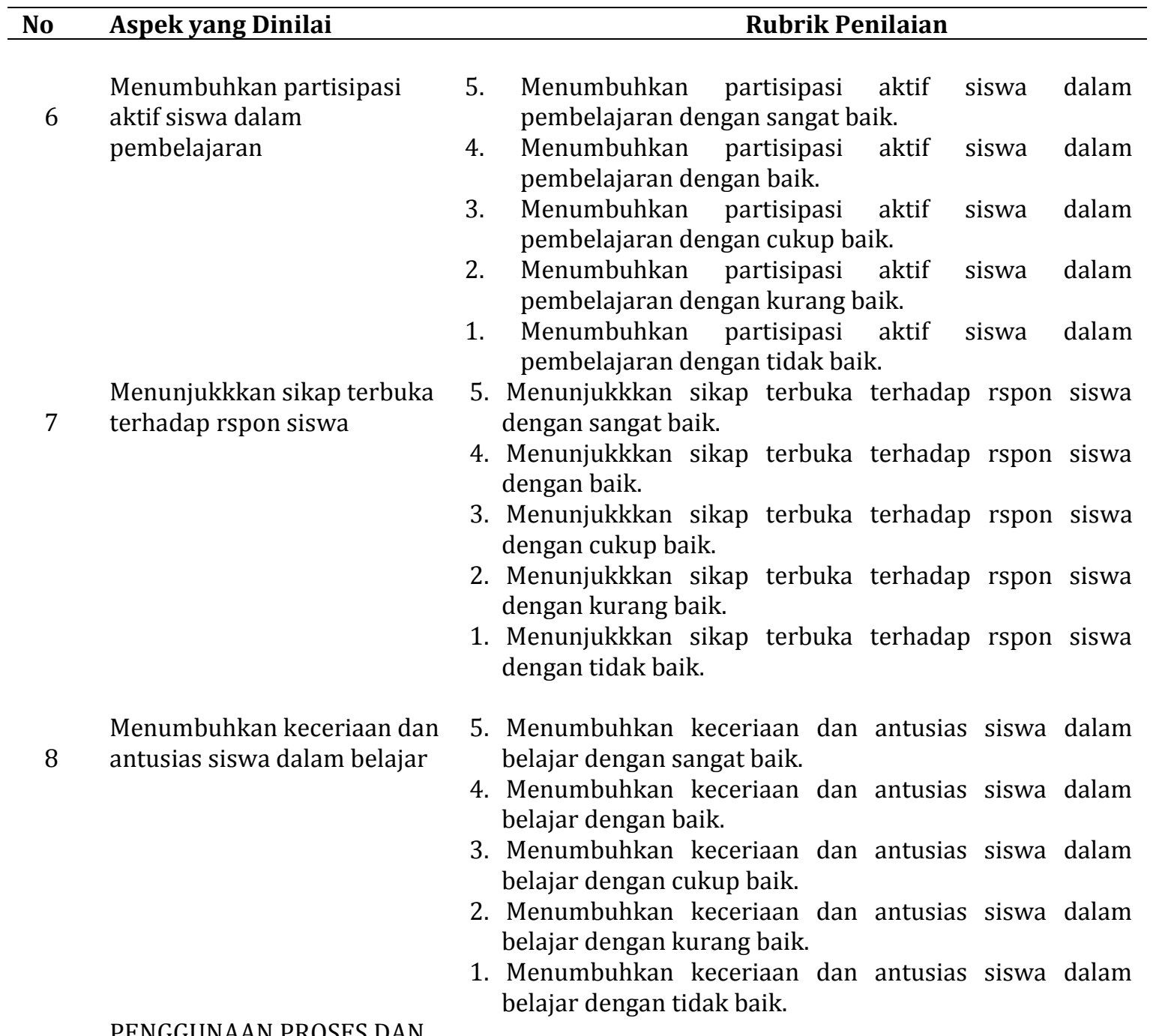

HASIL BELAJAR

Memantau kemajuan belajar selama proses

Melakukan penilaian akhir sesuai dengan kompetensi (tujuan)

Penggunaan Bahasa

Menggunakan bahasa lisan

1 dan tulisan secara jelas, baik, dan benar
5. Memantau kemajuan belajar selama proses dengan sangat baik.

4. Memantau kemajuan belajar selama proses dengan baik.

3. Memantau kemajuan belajar selama proses dengan cukup baik.

2. Memantau kemajuan belajar selama proses dengan kurang baik.

1. Memantau kemajuan belajar selama proses dengan tidak baik.

5. Melakukan penilaian akhir sesuai dengan kompetensi (tujuan) dengan sangat baik.

4. Melakukan penilaian akhir sesuai dengan kompetensi (tujuan) dengan baik.

3. Melakukan penilaian akhir sesuai dengan kompetensi (tujuan) dengan cukup baik.

2. Melakukan penilaian akhir sesuai dengan kompetensi (tujuan) dengan kurang baik.

1. Melakukan penilaian akhir sesuai dengan kompetensi (tujuan) dengan tidak baik.

5. Menggunakan bahasa lisan dan tulisan secara jelas, baik, dan benar secara sangat baik.

4. Menggunakan bahasa lisan dan tulisan secara jelas, baik, 


\begin{tabular}{|c|c|c|}
\hline No & Aspek yang Dinilai & Rubrik Penilaian \\
\hline & & $\begin{array}{l}\text { dan benar secara sangat baik. } \\
\text { 3. Menggunakan bahasa lisan dan tulisan secara jelas, baik, } \\
\text { dan benar secara sangat baik. } \\
\text { 2. Menggunakan bahasa lisan dan tulisan secara jelas, baik, } \\
\text { dan benar secara sangat baik. } \\
\text { 1. Menggunakan bahasa lisan dan tulisan secara jelas, baik, } \\
\text { dan benar secara sangat baik. }\end{array}$ \\
\hline 2 & $\begin{array}{l}\text { Menyampaikan pesan dengan } \\
\text { gaya yang sesuai }\end{array}$ & $\begin{array}{l}\text { 5. Menyampaikan pesan dengan gaya yang sesuai dengan } \\
\text { sangat baik. } \\
\text { 4. Menyampaikan pesan dengan gaya yang sesuai dengan } \\
\text { baik. } \\
\text { 3. Menyampaikan pesan dengan gaya yang sesuai dengan } \\
\text { cukup baik. } \\
\text { 2. Menyampaikan pesan dengan gaya yang sesuai dengan } \\
\text { kurang baik. } \\
\text { 1. Menyampaikan pesan dengan gaya yang sesuai dengan } \\
\text { tidak baik. }\end{array}$ \\
\hline & PENUTUP & \\
\hline 3 & $\begin{array}{l}\text { Melakukan refleksi atau } \\
\text { membuat rangkuman dengan } \\
\text { melibatkan siswa }\end{array}$ & $\begin{array}{l}\text { 5. Melakukan refleksi atau membuat rangkuman dengan } \\
\text { melibatkan siswa dengan sangat baik. } \\
\text { 4. Melakukan refleksi atau membuat rangkuman dengan } \\
\text { melibatkan siswa dengan baik. } \\
\text { 3. Melakukan refleksi atau membuat rangkuman dengan } \\
\text { melibatkan siswa dengan cukup baik. } \\
\text { 2. Melakukan refleksi atau membuat rangkuman dengan } \\
\text { melibatkan siswa dengan kurang baik. } \\
\text { 1. Melakukan refleksi atau membuat rangkuman dengan } \\
\text { melibatkan siswa dengan tidak baik. }\end{array}$ \\
\hline 4 & $\begin{array}{l}\text { Melaksanakan tindak lanjut } \\
\text { dengan memberikan arahan } \\
\text { atau kegiatan atau tugas } \\
\text { bagian remidi (pengayaan) }\end{array}$ & $\begin{array}{l}\text { 5. Melaksanakan tindak lanjut dengan memberikan arahan } \\
\text { atau kegiatan atau tugas bagian remidi (pengayaan) } \\
\text { dengan sangat baik. } \\
\text { 4. Melaksanakan tindak lanjut dengan memberikan arahan } \\
\text { atau kegiatan atau tugas bagian remidi (pengayaan) } \\
\text { dengan baik. } \\
\text { 3. Melaksanakan tindak lanjut dengan memberikan arahan } \\
\text { atau kegiatan atau tugas bagian remidi (pengayaan) } \\
\text { dengan cukup baik. } \\
\text { 2. Melaksanakan tindak lanjut dengan memberikan arahan } \\
\text { atau kegiatan atau tugas bagian remidi (pengayaan) } \\
\text { dengan kurang baik. } \\
\text { 1. Melaksanakan tindak lanjut dengan memberikan arahan } \\
\text { atau kegiatan atau tugas bagian remidi (pengayaan) } \\
\text { dengan tidak baik. }\end{array}$ \\
\hline
\end{tabular}

Data kemampuan guru melaksanakan proses pembelajaran dianalisis menggunakan analisis statistik deskriptif. Pada penelitianini yang dihitung adalah rata-rata kemampuan guru dan persentase kemampuan guru melaksanakan proses pembelajaran yang akan digunakan untuk mengetahui tingkat kemampuan guru melaksanakan proses pembelajaran dengan membandingkan persentase tersebut ke dalam ke dalam PAP skala lima. Pada tabel 3 di bawah ini, dijabarkan pedomana konversi skala lima. 
Tabel 3. Pedoman Konversi Skala Lima

\begin{tabular}{c|c}
\hline Persentase (\%) & Kriteria \\
\hline $90-100$ & Sangat Baik \\
$75-89$ & Baik \\
$65-74$ & Cukup \\
$40-64$ & Kurang \\
$0-39$ & Sangat Kurang \\
\hline
\end{tabular}

Sumber: Dantes (2009)

Indikator keberhasilan penelitian ini adalah apabila kemampuan guru dalam melaksanakan proses pembelajaran secara individu telah mencapai rata-rata $\geq 80$, dan tingkat kemampuan guru melaksanakan proses pembelajaran sebesar $80 \%$ yang berada pada kategori baik.

\section{Hasil dan pembahasan}

Kondisi pada prasiklus terlihat siswa kurang aktif dalam mengikuti proses pembelajaran. Guru lebih banyak menjelaskana materi dan memberikan tugas. Berdasarkan hasil analisis data diperoleh ratarata kemampuan guru dalam melaksanakan pembelajaran sebesar 65,42 dengan tingkat kemampuan guru sebesar $65,42 \%$ yang tergolong cukup. Untuk meningkatkan kemampuan guru dalam melaksanakan pembelajaran dilakukan melalui penerapan supervisi klinis.

Pada siklus I guru menyiapkan RPP sambil melakukan diskusi dengan kepala sekolah tentang kendala yang dihadapi pada saat proses pembelajaran. Kepala sekolah memberikan masukan atau solusi dan tentu saja dibahas bersama dengan guru.

Pada tahap pelaksanaan pertemuan awal atau pertemuan pendahuluan adalah dialog antara kepala sekolah dengan guru. Kegiatan dalam pertemuan tersebut hendaknya menghasilkan kesepakatankesepakatan tentang identifikasi kesulitan yang dialami dan dihadapi guru dalam melaksanakan proses pembelajaran dan faktor penyebabnya, Kepala sekolah bersama guru membahas beberapa alternatif jenis tindakan pembelajaran dan guru harus menetapkan salah satu jenis tindakan yang akan dicoba untuk memecahkan masalah tersebut, guru dibantu kepala sekolah menyusun program tindakan pembelajaran, keberhasilan tindakan pembelajaran, menyusun instrumen untuk mengukur kemampuan guru mengajar, serta menetapkan jadwal pelajaran.

Sesuai dengan jadwal yang telah ditentukan pada pertemuan awal langkah kedua dari supervisi klinis adalah guru mengajar dan kepala sekolah mengamati perilaku guru dalam melaksanakan proses pembelajaran. Pada pertemuan balikan yakni pertemuan kepala sekolah dan guru yang bertujuan untuk menganalisis hasil tindakan guru serta menetapkan keputusan cara pemecahan masalah pembelajaran yang dialami guru. Guru terlebih dahulu menyampaikan kelebihan dan kekurangannya dalam melaksanakan proses pembelajaran. Selanjutnya kepala sekolah menyampaikan hasil observasi yang telah dilakukan. Kemudian guru dan kepala sekolah membahas kekurangan dalam proses pembelajaran yang dilakukan guru dan menentukan cara memperbaikinya.

Secara umum pelaksanaan supervisi klinis sesuai dengan rencana. Hasil observasi yang dilakukan terhadap kemampuan guru dalam melaksanakan pembelajaran dan hasil analisis data diperoleh rata-rata kemampuan guru melaksanakan pembelajaran sebesar 73,96 dengan persentase sebesar 73,96\% setelah dibandingkan ke dalam PAP skala lima tingkat kemampuan guru dalam melaksanakan pembelajaran sebesar 73,96\% berada pada rentangan 65-74 yang tergolong cukup.

Dilihat dari hasil observasi terhadap kemampuan guru dalam melaksanakan pembelajaran dalam kategori cukup. Kelemahan-kelemahan yang tampak adalah dalam menyajikan pembelajaran, guru masih sedikit sekali mengaitkan pembelajaran dengan pengalaman siswa sehari. Selain itu dalam memberikan penghargaan, membangkitkan semangat ingin tahu, serta membangkitkan semangat belajar siswa masih terasa kurang. Hal seperti itu dapat terjadi karena kebiasaan guru dalam menyajikan pembelajaran terlalu mengacu pada target pencapain kurikulum sehingga mengabaikan hal yang nampaknya sepele tetapi sebenarnya sangat mempengaruhi hasil belajar.

Secara umum pelaksanaan supervisi klinis sudah dapat berjalan dengan baik. Semangat guru-guru untuk meningkatkan kemampuannya dalam pembelajaran merupakan faktor penentu keberhasilan sebuah tindakan. Namun demikian ada beberapa indikator yang masih memerlukan perbaikan pada tindakan berikutnya, antara lain guru belum melaksanakan pembelajaran sesuai rancangan dan guru belum tampil maksimal dalam pembelajaran. Sebenarnya rancangan pembelajaran sudah dibuat dengan baik, tetapi nampaknya karena dilihat dan diobservasi oleh kepala sekolah guru kelihatan agak gerogi 
sehingga melupakan rancangan yang sudah dibuat. Sementara itu dari sisi siswa juga nampak ada kekakuan dan nampak sedikit terganggu dengan kehadiran kepala sekolah. Dengan adanya masalah seperti ini peneliti menyarankan agar sosialisasi kepada siswa harus dilakukan dengan sebaik mungkin untuk memberikan pengertian dan pemahaman kepada siswa tentang tujuan supervisi yang diadakan.

Sebelum dilaksanakannya tindakan pada siklus II untuk mengamati keefektifan pelaksanaan supervisi klinis dalam rangka meningkatkan kemampuan guru dalam melaksanakan pembelajaran, terlebih dahulu peneliti melakukan diskusi dengan guru-guru. Pertemuan ini membahas tetang hasil refleksi dari kegiatan pada siklus I. Pada kesempatan tersebut, peneliti kembali menyampaikan kelebihan ataupun kekurangan dari pada pelaksanaan siklus I. Melalui diskusi kemudian disepakati untuk melakukan perbaikan-perbaikan dari kelemahan ataupun kekurangan tersebut, serta memperhatikan dan mempertahankan hal-hal yang sudah terlaksana pada siklus pertama.

Dalam kegiatan ini juga, guru-guru kemudian kembali bekerja untuk menyiapkan materi ajar, menyusun rancangan pembelajaran, serta menyiapkan media dan alat peraga pembelajaran yang diperlukan. Pertemuan awal atau pertemuan pendahuluan adalah dialog antara kepala sekolah dengan guru. Kemudian sesuai dengan jadwal yang telah ditentukan pada pertemuan awal langkah kedua dari supervisi klinis adalah guru mengajar dan kepala sekolah mengamati perilaku guru dalam melaksanakan proses pembelajaran. Pertemuan balikan yakni pertemuan kepala sekolah dan guru yang bertujuan untuk menganalisis hasil tindakan guru serta menetapkan keputusan cara pemecahan masalah pembelajaran yang dialami guru. Dalam pertemuan balikan kepala sekolah harus banyak mendengar apa yang disampaikan guru, memberikan komentar kepada guru pada saat-saat diperlukan, menghargai usaha guru memberikan dukungan, jangan banyak memberi nasihat dan saran terlebih lagi memberi kritik tajam.

Tindak lanjut dari pertemuan balikan adalah kepala sekolah membina guru bersangkutan agar selalu memperbaiki kekurangan dirinya dalam melaksanakan pembelajaran. Oleh sebab itu guru disarankan untuk kembali mempraktekan tindakan pembelajaran dalam upaya memperbaiki kekurangan dirinya dalam melaksanakan pembelajaran. Sebaliknya kepala sekolah memantau dan menilai perubahan-perubahan yang terjadi pada guru yang bermasalah dalam melaksanakan pembelajaran.

Secara umum tahapan-tahapan pelaksanaan supervisi klinis yang dilakukan sesuai dengan rencana. Hasil observasi yang dilakukan terhadap pelaksanaan pembelajaran nampak terjadi peningkatan dibandingkan dengan kegiatan pada siklus pertama. Hasil observasi yang dilakukan terhadap kemampuan guru dalam melaksanakan pembelajaran kemudian dianalisis diperoleh rata-rata kemampuan guru melaksanakan proses pembelajaran dalam PAP skala lima, maka tngkat kemampuan guru dalam melaksanakan pembelajaran sebesar $82,60 \%$ berada pada rentangan $75-89$ yang tergolong baik.

Pada siklus II proses pembelajaran yang dilaksanakan oleh guru sudah meningkat dibandingkan dengan siklus I. Kemampuan guru dalam menggunakan berbagai cara membangkitkan semangat belajar siswa (memberikan motivasi) masih perlu ditingkatkan. Usaha untuk meningkatkan motivasi belajar siswa memerlukan kondisi tertentu yang mengedepankan keterlibatan dan keaktifan siswa dalam pembelajaran. Sejauh mungkin siswa perlu didorong untuk mampu menata belajarnya sendiri dan menggunakan interaksi antarpribadi dengan teman dan guru untuk mengembangkan kemampuan kognitif/intelektual dan kemampuan sosial. Indikator ini kurang mendapat perhatian guru mungkin karena dalam pembelajaran sebagian besar siswa sudah menampakkan keaktifan. Tetapi walaupun demikian, setelah mencermati dari hasil observasi terhadap kemampuan guru dalam melaksanakan pembelajaran secara keseluruhan menampakan hasil dalam katagori baik. Hal ini menunjukkan bahwa penerapan supervisi klinis yang dilakukan cukup efektif. Oleh karena indikator keberhasilan sudah tercapai maka siklus dicukupkan sampai siklus II.

Berdasarkan hasil analisis data dari prasiklus sampai ke siklus II dapat dilihat pada rekap hasil penelitian pada tabel 4 .

Tabel 4. Rekap Hasil Penelitian

\begin{tabular}{c|c|c|c}
\hline No & Siklus & Rata-Rata & Rata-Rata Persen \\
\hline 1 & Pra & 65,42 & 65,42 (Cukup) \\
2 & I & 73,96 & 73,96 (Cukup) \\
3 & II & 82,60 & 82,60 (Baik) \\
\hline
\end{tabular}

Supervisi klinis yang dilakukan oleh kepala sekolah merupakan bentuk layanan dan bantuan untuk meningkatkan kualitas mengajar guru di kelas yang pada gilirannya untuk meningkatkan kualitas hasil belajar siswa. Untuk itu, supervisi klinis harus dilaksanakan berdasarkan data dan fakta yang obyektif. 
Supervisi klinis yang dilakukan kepala sekolah sangatlah berpengaruh pada peningkatan kinerja guru, karena hal itu sangat mendukung pada proses pelakasanaan pembelajaran di dalam kelas, dengan adanya supervisi klinis ini sangat mendukung pada peningkatan kinerja guru.

Hasilnya banyak perubahan yang terjadi di diri para guru yang sebelum para guru sering membuat metode pembelajaran yang konvensional sekarang sudah ada perubahan sedikit yang membuat model pembelajaran yang beragam. Dengan begitu, supervisi klinis diterapkan kepala sekolah mengolah kata yang baik untuk mereka itu bisa membuat para guru merasa nyaman dan tidak sungkan apabila ada konsultasi terhadap keluhan dalam proses pembelajaran. Suatu hal yang paling menentu dalam pelaksanaan supervisi klinis adalah kepekaan dari kepala sekolah dalam melihat problematika yang terjadi di lembaga pendidikan. Kepekaan kepala sekolah sangat membantu pula dalam pengembangan kompetensi guru yang bersangkutan. Kepala sekolah akan dapat mendorong guru untuk dapat berbuat lebih baik dan lebih banyak untuk lembaga pendidikan yang dipimpinya.

Pelaksanaan supervisi klinis yang baik akan berdampak pada kesadaran diri guru yang ada untuk memperbaiki kinerja mereka. Kepala sekolah harus melihat guru sebagai partner, bukan bawahan.Kepala sekolah dengan pendekatan personal dan kunjungan kelas ini lebih bisa efektif dalam menyelesaikan masalah yang dialami guru. Kepala sekolah memberi kesempatan kepada guru mengemukakan apa yang menjadi perhatian utamanya yang kemudian dijabarkan ke dalam bentuk tingkah laku yang dapat diamati dalam setting proses pembelajaran. Jenis data mengajar yang akan diobservasi ditentukan. Instrument observasi dan cara mencatat data-data yang diperlukan disepakati bersama selama proses pembelajaran berlangsung.

Penelitian tentang supervisi klinis didukung oleh penelitian yang dilakukan oleh Wirawan (2010), melaksanakan sebuah penelitian dengan tujuan untuk mengetahui efektivitas supervisi klinis yang diterapkan pada guru-guru kelas I sekolah dasar pada gugus IV (Cempaka Putih) Kecamatan Kubutambahan telah memberikan hasil yang signifikan. Hasil penelitian menunjukkan bahwa dengan kegiatan supervisi klinis yang dilakukan kepala sekolah dasar dapat meningkatkan kinerja guru. Sedangkan Sunendra, (2012) melakukan penelitian yang menujukkan bahwa penerapan supervisi klinis dapat meningkatkan wawasan guru matematika SD Gugus V Kecamatan Sukasada tentang Permendiknas No. 41 tahun 2007.

Supervisi klinis akan lebih baik lagi jika guru yang disupervisi merasa bila mereka tidak disupervisi, melainkan diajaksharing terkait problematika pada kegiatan pembelajaran. Pemahaman seperti itu membuat para guru menjadi lebih terbuka terhadap hal apapun yang mereka alami selama mengajar. Para guru merasa lebih senang dengan supervisor internal sebab dengan demikian mereka merasa lebih diperhatikan oleh lembaga pendidikan. Setelah dilakukan supervisi klinis memang kemampuan melaksanakan proses pembelajaran guru menjadi lebih baik. Tapi yang paling penting hasil sebenarnya dari supervisi itu adalah mutu lembagapendidikan menjadi lebih baik.

\section{Simpulan dan saran}

Berdasarkan pemaparan dan hasil analisis, maka dapat disimpulkan bahwa implementasi supervis klinis dapat meningkatkan kemampuan melaksanakan proses pembelajaran pada guru SD Negeri 2 Petandakan semester II tahun pelajaran 2019/2020. Hal ini terlihat dari peningkatan kemampuan guru melaksanakan proses pembelajaran yaitu pada prasiklus tingkat kemampuan guru melaksanakan pembelajaran sebesar $65,42 \%$ yang tergolong cukup, pada siklus II menjadi 73,96 yang tergolong cukup, dan pada siklus II menjadi 82,60 yang tergolong baik.

Berdasarkan kesimpulan hasil penelitian maka penulis menyarankan kepada guru-guru agar lebih memahami siswa yang belajar adalah individu-individu yang memiliki potensi dan kemampuan berpikir kritis dan kreatif. Karenanya, mereka harus diberi kesempatan untuk memikirkan segala sesuatu yang terjadi dalam lingkungannya; guru hendaknya menstimulasi daya pikir mereka dengan mengajukan sejumlah pertanyaan dan permasalahan yang harus dipecahkan (problem solving). Melalui penciptaan kondisi yang menantang dan pemberian kebebasan yang luas kepada siswa untuk beraktifitas, memungkinkan siswa menganalisis permasalah secara kritis, dan mencari pemecahannya secara kreatif. Kepada Kepala Sekolah, upaya untuk meningkatkan kemampuan guru dalam mutu pembelajarannya di kelas semestinya selalu dilakukan, karena kualitas pembelajaran memberikan implikasi terhadap hasil belajar yang diperoleh siswa.

\section{Daftar Rujukan}

Agustini, D. . dkk. (2019). Implementasi Supervisi Klinis dalam Meningkatkan Kompetensi Profesional Guru di Sekolah Dasar. Prosiding Seminar Nasional Pendidikan Program Pascasarjana Universitas 
PGRI Palembang.

Anwar, M. (2018). Menjadi Guru Profesional. Jakarta: Prenadamedia Grup.

Banun, S. (2016). Strategi Kepala Sekolah dalam Meningkatkan Mutu Pendidikan Pada SMP Negeri 2 Unggul Mesjid Raya Kabupaten Aceh Besar. Jurnal Administrasi Pendidikan, 4(1).

Fitriani, C. (2017). Kompetensi Profesional Guru Dalam Mengelola Pembelajaran Di MTs Muhammadiyah Banda Aceh. Jurnal Magister Administrasi Pendidikan, 5(2).

Mulyasa. (2005). Menjadi Guru Profesional. Bandung: Remaja Rosida Karya.

Purwanto, N. (2006). Admisntrasi dan Supervisi Pendidikan. Bandung: Remaja Rosdakarya.

Ranjawali, Ronexon Mbelu, Ade Iriani, \& W. (2019). Evaluasi Pelaksanaan Supervisi Klinis Dalam Peningkatan Standar Proses Dikalangan Guru-guru Matematika di SMA Negeri 1 Pandawai. Jurnal Manajemen Pendidikan, 14(1).

Sagala, S. (2020). Supervisi Pembelajaran dalam Profesi Pendidikan. Bandung: Alfabeta.

Salma, P. (2018). Pelaksanaan Supervisi klinis dalam Meningkatkan Kompetensi Profesional Guru di MAN Beureunuen. Jurnal Magister Administrasi Pendidikan, 6(1).

Sulfemi, W. B. (2015). Kemampuan Pedagogi Guru. Prosiding Seminar Nasional STKIP Muhammadiyah Bogor, 1(1).

Sunendra. (2012). Peningkatan Keterampilan Menyusun RPP Berorientasi Permendiknas No. 41 Tahun 2007 Melalui Pelatihan Supervisi Klinis Pada Para Guru SD Gugus V Kecamatan Sukasada.

Supriyono, A. (2017). Pengaruh Kompetensi Pedagogi, Profesional, Dan Motivasi Kerja Terhadap Kinerja Guru Sekolah Dasar. Jurnal Pendidikan, 18(2).

Syaidah,Umu, Bambang Suyadi, \& H. M. A. (2018). Pengaruh Kompetensi Guru Terhadap Hasil Belajar Ekonomi Di SMA Negeri Rambipuji Tahun Ajaran 2017/2018. Jurnal Pendidikan Ekonomi, 12.

Undang-Undang RI Nomor 14 Tahun 2005 Tentang Guru dan Dosen. (n.d.).

Yurizki, D. (2018). Kompetensi Pedagogik dan Profesional Guru dalam Peningkatkan Hasil Belajar Fisika Peserta Didik SMAN di Wilayah Barat Kabupaten Bireuen. Jurnal Pendidikan Sains Indonesia, 6(2), 68-74. 